University of Nebraska - Lincoln

DigitalCommons@University of Nebraska - Lincoln

1999

\title{
Are Shifts in Herbicide Use Reflected in Concentration Changes in Midwestern Rivers?
}

William Battaglin

U. S. Geological Survey, Box 25046, MS 406, Denver, Colorado

Donald Goolsby

U. S. Geological Survey, Box 25046, MS 406, Denver, Colorado

Follow this and additional works at: https://digitalcommons.unl.edu/usgsstaffpub

Part of the Earth Sciences Commons

Battaglin, William and Goolsby, Donald, "Are Shifts in Herbicide Use Reflected in Concentration Changes in Midwestern Rivers?" (1999). USGS Staff -- Published Research. 81.

https://digitalcommons.unl.edu/usgsstaffpub/81

This Article is brought to you for free and open access by the US Geological Survey at DigitalCommons@University of Nebraska - Lincoln. It has been accepted for inclusion in USGS Staff -- Published Research by an authorized administrator of DigitalCommons@University of Nebraska - Lincoln. 
Are Shifts in Herbicide Use Reflected in Concentration Changes in Midwestern Rivers?

\author{
WILLIAM A. BATTAGLIN* AND \\ DONALD A. GOOLSBY \\ U. S. Geological Survey, Box 25046, MS 406, \\ Denver, Colorado 80225
}

In many Midwestern rivers, elevated concentrations of herbicides occur during runoff events for $1-3$ months following application. The highest or "peak" herbicide concentration often occurs during one of these runoff events. Herbicide concentrations in rivers are affected by a number of factors, including herbicide use patterns within the associated basin. Changing agricultural practices, reductions in recommended and permitted herbicide applications, shifts to new herbicides, and greater environmental awareness in the agricultural community have resulted in changes to herbicide use patterns. In the M idwestern United States, alachlor use was much larger in 1989 than in 1995, while acetochlor was not used in 1989, and commonly used in 1995. Use of atrazine, cyanazine, and metolachlor was about the same in 1989 and 1995. Herbicide concentrations were measured in samples from $53 \mathrm{M}$ idwestern rivers during the first major runoff event that occurred after herbicide application (postapplication) in 1989, 1990, 1994, and 1995. The median concentrations of atrazine, alac hlor, cyanazine, metribuzin, metolachlor, propazine, and simazine all were significantly higher in 1989/90 than in 1994/95. The median acetochlor concentration was higher in 1995 than in 1994. Estimated daily yields for all herbicides and degradation products measured, with the exception of acetochlor, were higher in 1989/90 than in 1994/95. The differences in concentration and yield do not always parallel changes in herbicide use, suggesting that other changes in herbicide or crop management are affecting concentrations in Midwestern rivers during runoff events.

\section{Introduction}

A review of studies of long-term trends in pesticideoccurrence in surface water is given by Larson et al. (1). Many of these studies weretargeted at identifying trendsin organochlorine and organophosphorus insecticide concentrations. Larson et al. (1) indicated that the lack of consistent and detailed data on herbicide concentrations in surface waters of the United States has limited researchers' ability to determine if long-term changes in herbicide concentrations are occurring. A study (2) of LakeErie tributaries from 1983 to 1991 showed no significant trends in monthly mean concentrations of alachlor, atrazine, or metolachlor over the 9-year period. Annual mean atrazine concentrations for the Mississippi River at Vicksburg for 1975-1989 were computed from data collected by Ciba-Geigy (3). Over the14-year period,

* Correspondingauthor phone: (303)236-5950x202; fax: (303)2365919; e-mail: wbattagl@usgs.gov.

10.1021/es9900149 Not subject to U.S. Copyright. Publ. 1999 Am. Chem. Soc. Published on Web 07/27/1999 no significant trend was observed, but there was some indication that annual mean concentrations decreased recently from the highest levels, measured in the early 1980 s (4). More recent data indicate that between 1991 and 1997, estimates of annual atrazine, cyanazine, and metolachlor flux to the Gulf of Mexico stayed about the same, whereas estimates of annual alachlor flux decreased, and estimates of acetochlor flux increased (5).

A few studies have investigated changes in herbicide concentration in groundwater. Kolpin et al. (6) studied temporal trends in herbicide concentration from selected wells in lowa. Results indicate that between 1982 and 1995, the concentration of atrazine in lowa groundwater showed a significant downward trend, concentration of metolachlor showed a significant upward trend, and concentrations of alachlor and cyanazine showed no discernible trend. The changes in concentration were only marginally related to changes in herbicide use. In lowa, between 1982 and 1995, the use of alachlor decreased the most (more than $60 \%$ ), atrazine use decreased by $12 \%$, cyanazine use decreased by $26 \%$, and metolachlor use increased by $54 \%$. A study of Wisconsin ground water also identified a downward trend in atrazine concentration and associated that trend with a downward trend in atrazine use (7).

The objective of this study was to determine if reductions that were expected in theuse of atrazineand alachlor between 1989 and 1995 would result in a reduction in atrazine and alachlor concentrations or daily yields during postapplication runoff events in Midwestern rivers. Secondary objectives included determining if changes since 1989/90 in the concentrations or daily yields of other herbicides have occurred and determining something about the occurrence of acetochlor, a new herbicide, as well as alachlor ethanesulfonic acid (ESA) and cyanazine amide, herbicide degradates not previously looked for in Midwestern rivers. The data collected for use in this study consist of only one postapplication runoff event sample per site per year. This is clearly less than ideal, but the large number of sites (53) still make this data set adequate to determine if changes in herbicide concentrations or daily yields during postapplication runoff events in Midwestern rivers have occurred between 1989 and 1995. The data set is not adequate to determine if changes in annual mean concentrations or annual yields have occurred.

\section{Experimental Section}

Study Area and Sampling Strategy. The study area consists of 53 Midwestern streams (Figure 1). These streams were originally selected to represent a stratified random sample of streams in 10 Midwestern States $(8,9)$. Water samples were collected from the streams numerous times during the period 1989-95. Samples were collected three timesin 1989: in spring, before herbicide application (preapplication), in early summer, after herbicideapplication and duringa major, ideally the first, postapplication runoff event (postapplication), and in fall during base-flow conditions (low-flow) (811). In 1990, samples were collected during pre- and postapplication periods. In 1994 and 1995, samples were again collected during postapplication periods (12). Only the postapplication samples from each year of sampling were used in this analysis. The intent of the postapplication samples was to capture the peak preemergence herbicide concentrations expected during the year $(1,9,13,14)$. Herbicide concentration data collected using automatic samplersin 1990 and 1991 (15) suggest that the peak herbicide concentrations often coincide with the first significant 


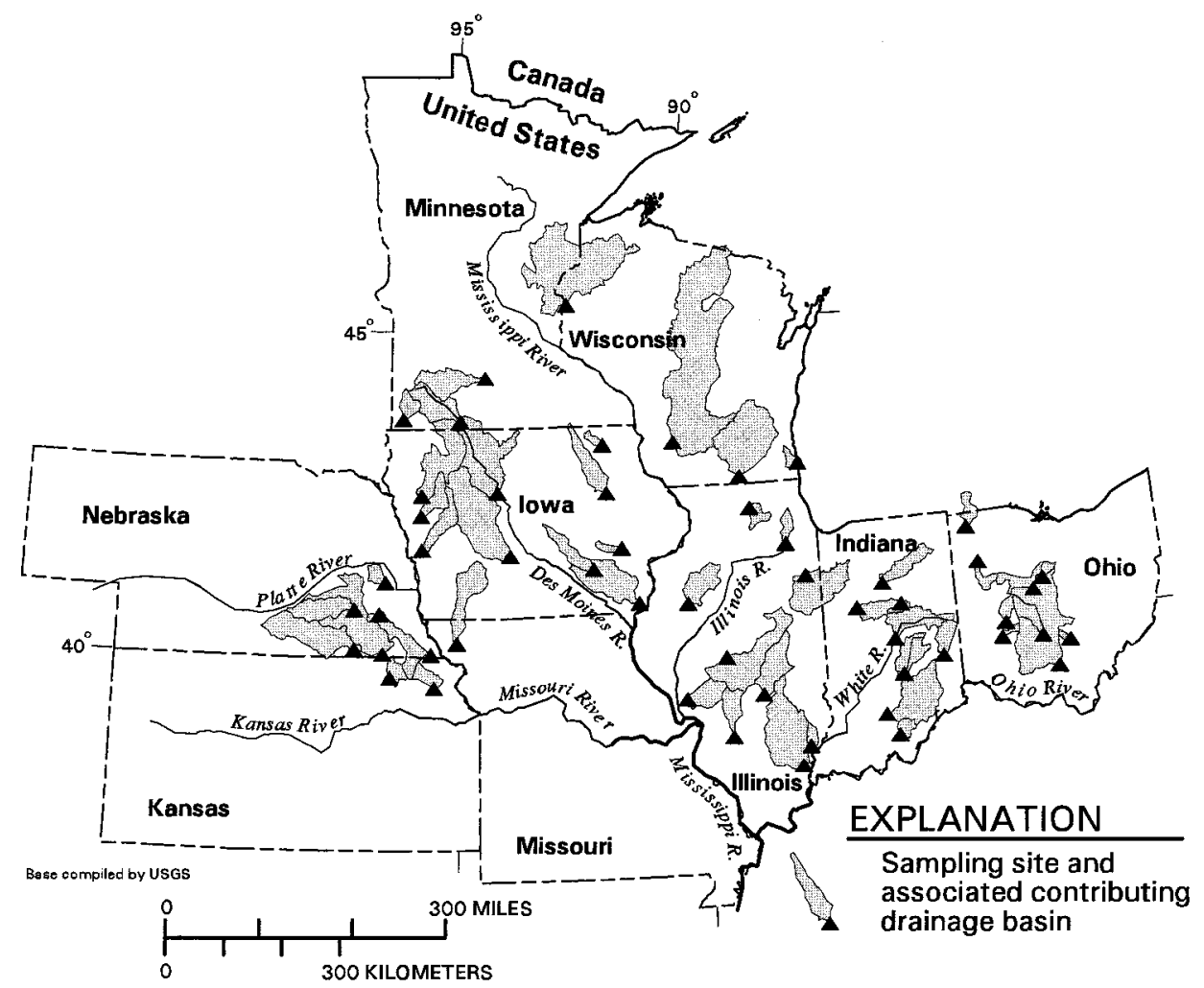

FIGURE 1. Location of sampled sites and associated drainage basins.

streamflow rise (runoff-event) after herbicide application. However, this samedata set demonstrates that peak herbicide concentrations are highly variable and, on some streams, can occur later in thesummer or during lower flow conditions than were sampled.

Sampling and Analytical Procedures. All samples were collected in glass or Teflon sampling bottles byU.S. Geological Survey personnel using a depth-integrating sampler from three or more verticals. The samples were filtered through glass fiber filters (0.7- or $1-\mu \mathrm{m}$ nominal poresize) at the time of collection to remove suspended materials. Streamflow, specific conductance, $\mathrm{pH}$, and temperature of the water were measured at the time of sample collection $(10,12,16)$. All samples were analyzed for 11 herbicides and 2 herbicide degradation products by gas chromatography/mass spectrometry (17). All samples from 1994 and 95 were also analyzed for one additional herbicide (acetochlor) and two additional herbicide degradation products (alachlor ESA and cyanazine amide) $(18,19)$. A list of analytes is given in Table 1. Complete details of the study methods, analytical procedures, and the raw analytical results are presented by Scribner et al. $(12,16)$.

\section{Results and Discussion}

Changesin Herbicide Use. Since 1989, changes in agricultural practices, reductions in recommended and permitted herbicide applications, shifts to new herbicides, and greater environmental awareness in theagricultural community have resulted in changes to herbicide use patterns. In 1990 and again in 1992, the producer of atrazine voluntarily reduced the maximum labeled application rates (20). Most noncropland uses of atrazine were not permitted after the 1992 label change. Ribaudo and Bouzaher report (21) that the average rate for atrazine on corn declined from 1.46 pounds per acre (lb/acre) in 1985 to $1.09 \mathrm{lb} /$ acre in 1993, a decrease of 25\%.

Estimates of the use of five herbicides and planted corn and soybean acreages in eight Midwestern states (IA, IL, IN,
KS, MN, NE, OH, and WI) for 1989 through 1996, are shown in Figure 2 (22-24). Herbicide use estimates and crop acreages from Michigan and $\mathrm{M}$ issouri are omitted from these totals even though parts of these states fall within the Corn Belt; this is due to the paucity of sampling sites in these states. Dramatic changes in use are shown for acetochlor and alachlor, but little change is observed for the other three herbicides or for planted corn and soybean acreages. In 1995, approximated 40 different herbicides were reported to have significant use on either corn or soybeans in the major producing states (24). Use of the 12 herbicides studied equaled about $80 \%$ of the approximately 75000 metric tons (MT) of active ingredient applied to corn, but only $20 \%$ of the approximately 25000 metric tons of herbicide active ingredient applied to soybean (24).

Year-to-year variability in planted acreages and subsequent herbicide use can make comparisons of change between individual years misleading. The use of atrazine and metolachlor clearly follow the pattern of corn acreage. A comparison of averaged 1989-90 herbicide use with averaged 1994-95 herbicide use is made here so that these changes can be compared with the changes in averaged herbicide concentrations and yields later in the report. The intent of this averaging is to account to some degree for the natural year-to-year variability in herbicide use, concentration, and yield. In the eight Midwestern states, alachlor use was 56\% less in 1994/ 95 (7400 MT) than that in 1989/90 (17 000 MT), atrazine use was 2\% less in 1994/95 (17 600 MT) than that in 1989/90 (18 000 MT), cyanazine use was $26 \%$ greater in 1994/95 (10 200 MT) than that in 1989/90 (8100 MT) and metolachlor use was 10\% greater in 1994/95 (16 400 MT) than that in 1989/90 (14 900 MT). Acetochlor was not used until 1994, but its use has increased rapidly (9200 MT in 1995).

Changes in Herbicide Concentrations. Herbicide concentrations in Midwestern rivers were expected to change between 1989 and 1995 as a result of shifts in herbicide use 
TABLE 1. Percentage of Samples with Concentrations at or above the Analytical Reporting Limit (detections) and Median Concentration from Postapplication Samples Collected in 1989, 1990, 1994, and 1995

\begin{tabular}{|c|c|c|c|c|c|c|c|c|c|}
\hline \multirow[b]{3}{*}{ property or compound } & \multirow{3}{*}{$\begin{array}{l}\text { reporting } \\
\text { limits } \\
(\mu \mathrm{g} / \mathrm{L})\end{array}$} & \multicolumn{8}{|c|}{ percentage of samples with compound detections and median concentrations $(\mu \mathrm{g} / \mathrm{L})$} \\
\hline & & \multicolumn{2}{|c|}{$1989(n=50)$} & \multicolumn{2}{|c|}{$1990(n=52)$} & \multicolumn{2}{|c|}{$1994(n=52)$} & \multicolumn{2}{|c|}{$1995(n=50)$} \\
\hline & & $\%$ & median & $\%$ & median & $\%$ & median & $\%$ & median \\
\hline \multicolumn{10}{|c|}{ Herbicides } \\
\hline acetochlor & 0.05 & $a$ & & $a$ & & 34.6 & $<0.05$ & 84.0 & 0.42 \\
\hline alachlor & 0.05 & 94.0 & 1.90 & 94.2 & 1.62 & 78.8 & 0.77 & 82.0 & 0.13 \\
\hline ametryn & 0.05 & 0.0 & & 1.9 & $<0.05$ & 0.0 & & 2.0 & $<0.05$ \\
\hline atrazine & 0.05 & 100.0 & 10.9 & 100.0 & 8.98 & 100.0 & 3.98 & 100.0 & 5.54 \\
\hline cyanazine & 0.05 & 76.0 & 2.65 & 82.7 & 2.24 & 94.2 & 1.15 & 90.0 & 1.35 \\
\hline metribuzin & 0.05 & 70.0 & 0.28 & 53.8 & 0.10 & 46.2 & $<0.05$ & 42.0 & $<0.05$ \\
\hline metolachlor & 0.05 & 94.0 & 2.50 & 98.1 & 3.07 & 94.2 & 1.74 & 100.0 & 1.66 \\
\hline prometon & 0.05 & 26.0 & $<0.05$ & 15.4 & $<0.05$ & 7.7 & $<0.05$ & 38.0 & $<0.05$ \\
\hline prometryn & 0.05 & 0.0 & & 0.0 & & 0.0 & & 2.0 & $<0.05$ \\
\hline propazine & 0.05 & 54.0 & 0.07 & 61.5 & 0.11 & 30.8 & $<0.05$ & 58.0 & 0.06 \\
\hline simazine & 0.05 & 70.0 & 0.21 & 65.4 & 0.09 & 55.8 & 0.07 & 68.0 & 0.08 \\
\hline terbutryn & 0.05 & 0.0 & & 0.0 & & 0.0 & & 0.0 & \\
\hline \multicolumn{10}{|c|}{ Herbicide Degradation Products } \\
\hline alachlor ESA & 0.10 & $a$ & & $a$ & & 100.0 & 4.75 & 100.0 & 1.55 \\
\hline cyanazine amide & 0.05 & $a$ & & a & & 94.1 & 0.57 & 90.0 & 0.47 \\
\hline deethylcyanazine & 0.05 & $a$ & & $a$ & & 15.7 & $<0.05$ & $a$ & \\
\hline deethylcyanazine amide & 0.50 & $a$ & & a & & 3.9 & $<0.05$ & $a$ & \\
\hline deethylatrazine & 0.05 & 96.0 & 0.77 & 100.0 & 0.87 & 96.2 & 0.75 & 96.0 & 0.43 \\
\hline deisopropylatrazine & 0.05 & 69.2 & 0.47 & 86.5 & 0.44 & 92.3 & 0.44 & 96.0 & 0.42 \\
\hline \multicolumn{10}{|c|}{ Field Parameters } \\
\hline streamflow $\left(\mathrm{m}^{3} / \mathrm{s}\right)$ & & 100.0 & 27.8 & 100.0 & 35.7 & 100.0 & 27.1 & 100.0 & 28.4 \\
\hline streamflow as a percentile & & 100.0 & 82.4 & 100.0 & 89.0 & 100.0 & 79.9 & 100.0 & 87.6 \\
\hline a Not analyzed. & & & & & & & & & \\
\hline
\end{tabular}

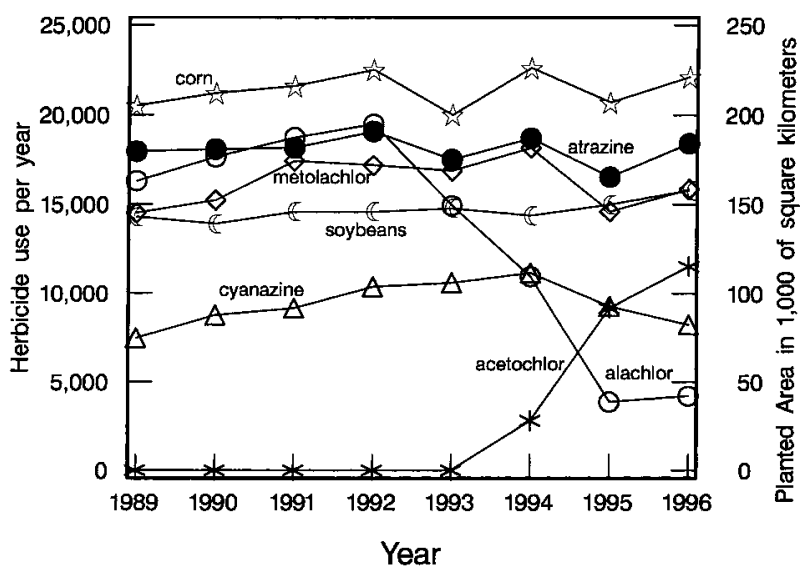

Herbicide use estimates are in metric tons of active ingredient Data Sources: Gianessi and Puffer, 1991; USDA, 1990-1997

FIGURE 2. Estimated use of five herbicides and planted corn and soybean acreage in eight Midwestern States (IA, IL, IN, KS, MN, $\mathrm{NE}, \mathrm{OH}$, and WI) for 1989-1996.

such as the decrease in alachlor use or the increase in acetochlor use. Alterations to crop management practices such as increased conservation tillage may also affect herbicide concentrations in some Midwestern rivers. One way to gain a measure of change is to look at the distribution of herbicide concentrationsfrom a set of representativesites such as those used in this study over a period of years. The distributions of concentrations for all herbicideand herbicide degradation products measured in this study, for all years, are positively skewed, suggesting that medians may bemore appropriate descriptors of central tendency of concentration distributions than means (25) and that nonparametric tests may be more appropriate for analysis than parametric tests, which are based on the assumption of data normality (26).

The percentage of samples with herbicides detected at or above the analytical reporting limit (detections) was greater in 1995 than in 1989 for five compounds (acetochlor, cyanazine, metolachlor, prometon, and propazine) and less in 1995 than in 1989 for three compounds (alachlor, metribuzin, and simazine). The detection frequency for atrazine was $100 \%$ in all 4 years (Table 1). Ametryn was detected only twice, prometryn was detected only once, and terbutryn was not detected. The frequency of detection of deethylatrazine was the same in 1989 and 1995 (96\%), but thefrequency of detection of deisopropylatrazine was greater in 1995 than in 1989. Alachlor ESA, cyanazine amide, deethylcyanazine, and deethylcyanazine amide were not analyzed in 1989 or 1990.

The median concentrations of herbicides in selected Midwestern rivers during postapplication runoff events was smaller in 1995 than that in 1989 for seven compounds (alachlor, atrazine, cyanazine, metribuzin, metolachlor, propazine, and simazine) and was the same (less than the detection limit) in 1989 and 1995 for four compounds (ametryn, prometon, prometryn, and terbutryn) (Table 1). Acetochlor was not used in 1989. The distributions of concentrations for eight herbicides and four herbicide degradation products are shown using boxplots in Figure 3. In Figure 3, nondetects are plotted at the reporting limit of theindividual compounds (Table 1 ), the boxes show the 25th, 50th (median), and 75th percentiles, the whiskers extend to the 5th and 95th percentiles, and outliers less than the 5th or greater than the 95th percentiles are shown as circles. The concentration distributions for alachlor, atrazine, cyanazine, metolachlor, metribuzin, and simazine all are shifted down (lower concentrations) in 1994 and 1995 samples relative to those of 1989 and 1990 samples. The shift down for alachlor is most significant, with the 25th percentile concentration in 1989 approximately equal to the 75th percentile concentration in 1995.

The median concentration of the degradation products deethylatrazine and deisopropylatrazine both were less in 1995than in 1989, butthedistributions of their concentrations 

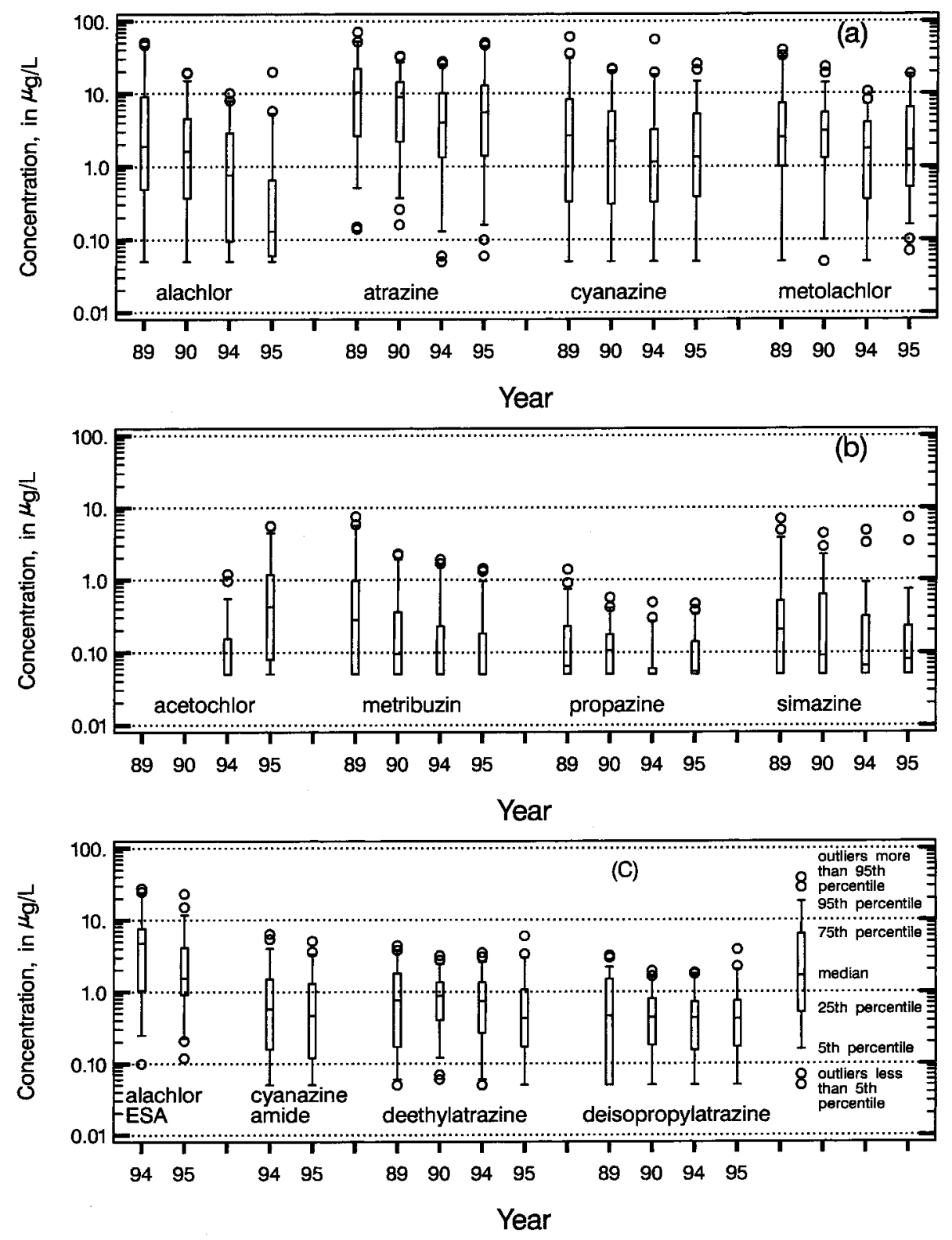

FIGURE 3. Boxplots of concentrations in selected Midw estern streams during postapplication runoff events in 1989, 1990, 1994, and 1995 for (a) alachlor, atrazine, cyanazine, and metolachlor; (b) ac etochlor, metribuzin, propazine, and simazine; and (c) alachlor ESA, cyanazine amide, deethylatrazine, and deisopropylatrazine.

were very similar (Figure 3). Alachlor ESA, cyanazine amide, deethylcyanazine, and deethylcyanazine amide were not analyzed in 1989 or 1990. The median deethylatrazine concentration was $0.77 \mu \mathrm{g} / \mathrm{L}$ in 1989 and $0.43 \mu \mathrm{g} / \mathrm{L}$ in 1995 , and the median deisopropylatrazineconcentration was 0.47 $\mu \mathrm{g} / \mathrm{L}$ in 1989 and $0.42 \mu \mathrm{g} / \mathrm{L}$ in 1995. Although median concentrationswereless in 1995 than those in 1989 for seven herbicides and two herbicide degradation products, Figure 3 indicates that in some cases these declines are not large and may not be statistically or environmentally significant.

The spatial patterns of alachlor and atrazine concentrations in postapplication runoff samples from 1989, 1990, 1994, and 1995 are shown on Figure 4. At sites in the Corn Belt where alachlor concentrations were largest, concentrations generally decreased from 1989/ 90 to 1994/95. The exception is in Nebraska basins where concentrations of alachlor did not decrease. Concentrations of atrazine appear to have decreased at some sites in Ohio and Indiana, but the difference is not as widespread or dramatic as that observed for alachlor. There appears to have been little change in atrazine concentrations at the sites in Nebraska. The dif- ferences between 1989 and 1990 and 1994 and 1995 concentrations (Figure 4) arean indication of annual variability.

Daily Yields. Daily herbicide yields were calculated at each site by multiplying herbicide concentrations with daily mean streamflow and dividing by drainage basin area. The intent of the postapplication runoff-event sampling was to capture the peak preemergence herbicide concentrations expected during the year at each site. Other studies $(9,11$, $14,15)$ have shown that the peak concentration for preemergence herbicides such as alachlor, atrazine, cyanazine, and metolachlor frequently occurs just after their application, during spring and early summer runoff events. Streamflow is also frequently near its annual maximum during these events. Hence, the daily yiel ds of herbicides calculated from these samples could reasonably be expected to approximate the peak daily yield expected for the year. However, it is not known if the calculated yiel ds are truly the maximum values for the year since it is not known if either the concentration or streamflow was truly at its peak.

Estimated peak daily herbicide yields were expected to change with shifts in herbicide use. The distributions of 

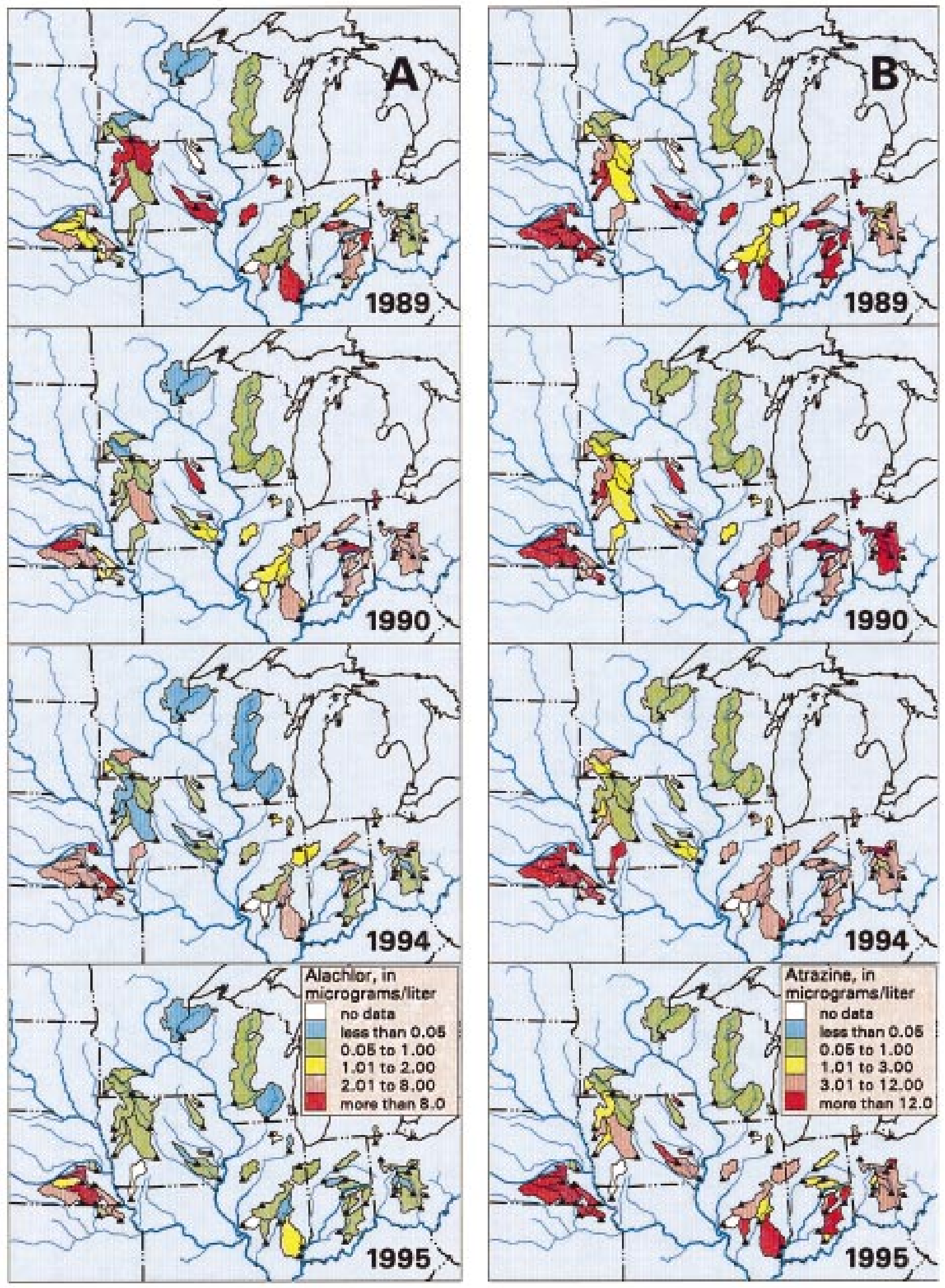

FIGURE 4. Concentrations in selected Midw estern streams during postapplication runoff events in 1989, 1990, 1994, and 1995 for (A) alachlor and $(B)$ atrazine. 

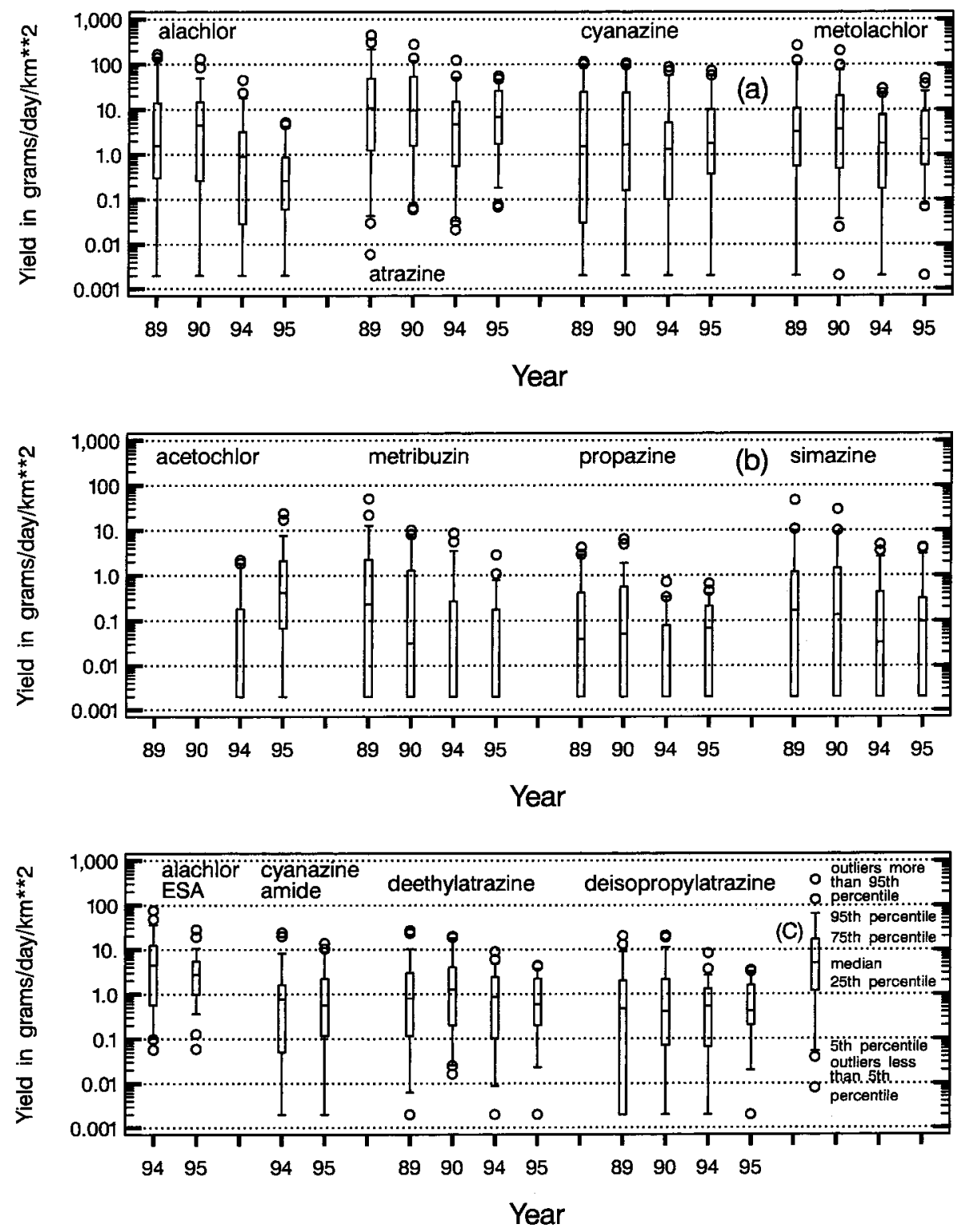

FIGURE 5. Boxplots of daily yields from selected Midw estern stream basins during postapplication runoff events in 1989, 1990, 1994, and 1995 for (a) alachlor, atrazine, cyanazine, and metolachlor; (b) acetochlor, metribuzin, propazine, and simazine; and (c) alachlor ESA, cyanazine amide, deethylatrazine, and deisopropylatrazine.

estimated daily yields for eight herbicides and four herbicide degradation products are shown in Figure 5. Distributions of estimated peak yields for all herbicides and herbicide degradation products, for all years, are positively skewed and fail tests of normality. When the herbicideor degradation product concentrations were less than the reporting limit, the daily yields were set to $0.002 \mathrm{~g}_{\text {day }}{ }^{-1} \mathrm{~km}^{-2}$, so that the data could be plotted on a log scale.

Median estimated peak daily yields of herbicides in selected Midwestern rivers during postapplication runoff events weregreater in 1995than in 1989 for threecompounds [acetochlor (not used in 1989), cyanazine, and propazine], less in 1995than that in 1989 for seven compounds (alachlor, atrazine, metribuzin, metolachlor, simazine, deisopropylatrazine, and deethylatrazine), and the same in 1995 and 1989 ( $0.002 \mathrm{~g} \mathrm{day}^{-1} \mathrm{~km}^{-2}$ ) for four compounds (ametryn, prometon, prometryn, and terbutryn). As with herbicide concentrations, some of the changes in median peak daily yields are small and may not be statistically significant (Figure 5).

Annual Variability. Year-to-year variability may obscure or accentuate actual changes in herbicide concentrations or yields in Midwestern rivers and could limit the ability of statistics such as a Kruskal-Wallis test to identify differences in their distributions. Year-to-year variability is likely the result of differences in local and regional climatic conditions and resulting farm management practices and cannot solely be attributed to changes in herbicide use. Streamflow is one indicator of local or regional climatic condition. Theamount and timing of precipitation and the resulting streamflow can havesignificanteffects on herbicideand herbicide metabolite concentrations. The boxplots in Figure $6 \mathrm{~A}$ show the distributions of streamflow on the day of postapplication sample collection for each of the four years. Figure $6 \mathrm{~A}$ indicates that flows in 1989 and 1995 were similar, whereas flows in 1990 weregenerally higher, and flows in 1994 were generally lower. Median streamflow during sample collection was $27.8 \mathrm{~m}^{3} / \mathrm{s}$ in $1989,35.7 \mathrm{~m}^{3} / \mathrm{s}$ in $1990,27.1 \mathrm{~m}^{3} / \mathrm{s}$ in 1994 , and $28.4 \mathrm{~m}^{3} / \mathrm{s}$ in 1995 (Table 1).

Streamflow from each samplewereconverted to percentile values based on the historical distributions of daily-streamflow values at each site. For example, a 90th percentile streamflow would be exceeded by only $10 \%$ of historic daily streamflow values at the site. Daily-streamflow data from 

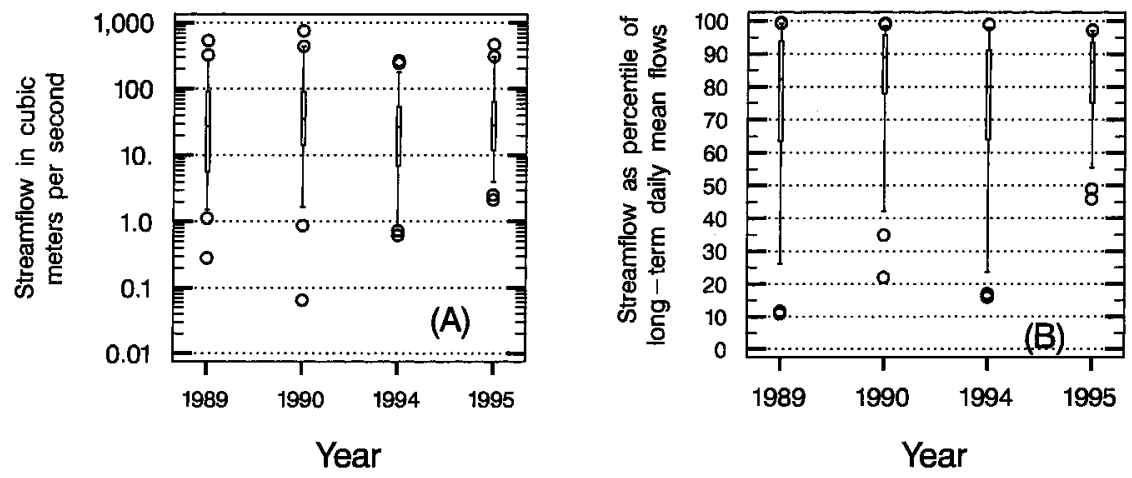

FIGURE 6. Boxplots of streamflow on the day of sample collection during postapplication runoff events in 1989, 1990, 1994, and 1995 (A) in cubic meters per second and (B) as a percentile of long-term daily streamflow.

TABLE 2. Median of Differences between Averaged 1994/95 and 1989/90 Herbicide Concentrations, Streamflow, and Streamflow Percentiles and Results from Wilcoxon Signed Rank Tests

\begin{tabular}{|c|c|c|c|c|}
\hline \multirow[b]{2}{*}{ compound or property } & \multirow{2}{*}{$\begin{array}{c}\text { median of paired differences } \\
\text { betw een averaged } \\
1994 / 95 \text { and } 1989 / 90 \text { concentrations }\end{array}$} & \multicolumn{2}{|c|}{ Wilcoxon signed rank test ressults } & \multirow[b]{2}{*}{ accept alternate hypothesis } \\
\hline & & signed rank & value & \\
\hline alachlor & 2.18 & 332 & $<0.001$ & yes \\
\hline atrazine & 3.03 & 269 & 0.005 & yes \\
\hline cyanazine & 1.09 & 288 & 0.002 & yes \\
\hline metribuzin & 0.12 & 277 & $<0.001$ & yes \\
\hline metolachlor & 1.32 & 219 & 0.023 & yes \\
\hline prometon & 0.0 & 5 & 0.912 & no \\
\hline propazine & 0.06 & 237 & 0.001 & yes \\
\hline simazine & 0.04 & 228 & 0.005 & yes \\
\hline deethylatrazine & 0.12 & 186 & 0.055 & no \\
\hline deisopropylatrazine & 0.10 & 140 & 0.140 & no \\
\hline streamflow $\left(\mathrm{m}^{3} / \mathrm{s}\right)$ & 6.33 & 138 & 0.159 & no \\
\hline streamflow percentile & 2.53 & 75 & 0.448 & no \\
\hline
\end{tabular}

TABLE 3. Median of Differences between Averaged $1994 / 95$ and 1989/90 Estimates of Herbicide Peak Daily Yields $\left(\mathrm{g} \mathrm{day}^{-1} \mathrm{~km}^{-2}\right.$ ) and Wilcoxon Signed Rank Test Results

\begin{tabular}{|c|c|c|c|c|}
\hline \multirow{2}{*}{$\begin{array}{l}\text { compound or property } \\
\text { (yield) }\end{array}$} & \multirow{2}{*}{$\begin{array}{c}\text { median paired differences } \\
\text { betw een averaged } \\
1994 / 95 \text { and } 1989 / 90 \text { peak daily yield }\end{array}$} & \multicolumn{2}{|c|}{ Wilcoxon signed rank test results } & \multirow[b]{2}{*}{ accept alternate hypothesis } \\
\hline & & rank & $p$ value & \\
\hline alachlor & 2.78 & 343 & $<0.001$ & yes \\
\hline atrazine & 5.26 & 281 & 0.003 & yes \\
\hline cyanazine & 1.09 & 212 & 0.023 & yes \\
\hline metribuzin & 0.217 & 253 & 0.001 & yes \\
\hline metolachlor & 0.696 & 202 & 0.037 & yes \\
\hline prometon & 0.0 & -22.5 & 0.635 & no \\
\hline propazine & 0.102 & 281 & $<0.001$ & yes \\
\hline simazine & 0.079 & 272 & 0.001 & yes \\
\hline deethylatrazine & 0.213 & 258 & 0.007 & yes \\
\hline deisopropylatrazine & 0.112 & 154 & 0.104 & no \\
\hline
\end{tabular}

1972 to 1991 were used to define the distribution of flows at each site. The percentile of flow may be preferable to actual streamflow in making comparisons between years and among basins of different sizes and flow regimes. The boxplots in Figure6B show the distributions of streamflow during sample collection as a percentile of long-term daily streamflow in each of the 4 years. Figure $6 \mathrm{~B}$ and Table 1 suggest that the distribution of sampled streamflow in 1990 and 1995 were similar and generally higher than flows in 1989 and 1994.

To gain a measure of changes in herbicideconcentrations and yields, a paired difference test was used. These tests can determine if one group of observations tends to be larger than another group. Since the distributions of concentrations (and yields) for all of the herbicides and herbicidedegradation products measured in this study, for all years, are positively skewed and the distributions of streamflow as a percentile are negatively skewed, the nonparametric Wilcoxon Signed Rank test $(25,26)$ was used. To reduce the effect of year- to-year variability, 1994 and 1995 concentrations, streamflows, flow percentiles, and estimates of daily yield at each site are averaged and subtracted from the average of 1989 and 1990 values. The following hypothesis was tested.

Null Hypothesis. Averaged 1989/90 concentrations/ streamflows/yields were not significantly different from averaged 1994/95 values (median of differences $=0$ ).

Alternate Hypothesis. Averaged 1989/ 90 concentrations/ streamflows/ yields were larger than 1994/ 95 values (median of differences $>0$ ) (one-sided test).

Medians of the calculated differences and results from the Wilcoxon Signed Rank test are given in Tables 2 and 3. The median concentration differences for all analyzed herbicides and herbicide degradation products with the exception of prometon are positive, indicating that concentrations were larger in 1989/ 90 than those in 1994/ 95 (Table 2). The concentration decreases for alachlor, atrazine, cyanazine, metribuzin, metolachlor, propazine, and simazine 
were all statistically significantly $(\rho \leq 0.05)$ according to the results of the signed rank tests. The differences between averaged 1989/ 90 and 1994/ 95 concentrations of prometon, deethylatrazineand deisopropylatrazinewerenot statistically significantly $(\rho>0.05)$. Averaged streamflow in cubic meters per second and streamflow percentiles were not significantly different in 1994/95 than in 1989/90 (Table 2), suggesting that when averaged 1989/90 flow conditions are comparable to $1994 / 95$ flow conditions and that annual variability is somewhat accounted for.

Results of Wilcoxon Signed Rank tests on differences between averaged 1989/90 and 1994/95 estimates of peak daily yield are given in Table 3 . The median yield differences with the exception of prometon are all positive, indicating that yields of all analyzed herbicides and herbicide degradation products were larger in 1989/ 90 than in 1994/95. The decreases in estimated daily yields for alachlor, atrazine, cyanazine, metribuzin, metolachlor, propazine, simazine, and deethylatrazinewerestatistically significantly $(\rho \leq 0.05)$. The differences between averaged 1989/ 90 and 1994/ 95 estimates of daily yield for prometon and deisopropylatrazine were not statistically significantly (Table 3 ).

Relation to Changes in Herbicide Use. The relation between changes in herbicide concentration or estimated peak daily yield and the change in overall use of each herbicide was not always as expected. Although thesignificant decrease in averaged alachlor use (56\%) between 1989/90 and 1994/95 paralleled significant decreases in the median alachlor concentration and daily yield, the same cannot be said for the other herbicides. Averaged atrazine use was slightly (2\%) smaller in 1994/ 95 than in 1989/90, in the eightstate region, but large decreases in median atrazine concentration and daily yield were observed. Metolachlor use was $10 \%$ larger in 1994/ 95 than that in 1989/90, but large decreases in median metolachlor concentrations and daily yields were observed. Cyanazine use was 26\% larger in 1994/ 95 than that in 1989/90, but significant decreases in median cyanazineconcentrationsand daily yields also were observed. The results for alachlor and acetochlor suggest that changes in herbicideuse do affect herbicide concentrations. However, the observed decreases in concentration and daily yield for several other herbicides cannot solely beattributed to changes in theoverall amount of their use. Other possible explanations for the decreases in herbicide concentrations and daily yields during postapplication runoff events include increased use of split herbicideapplications, decreased per acreapplication rates, increased use of postemergence herbicides $(24,27)$, increased postemergence application of traditionally preemergence compounds, and better utilization of herbicide best management practices.

Application of the results of this study is limited by a number of factors. First, peak herbicide concentrations are highly variable and one cannot always expect to get the true peak concentration when only one sample per year per site is collected. This is especially true now that many farms are using postemergence herbicides and some farmers apply preemergence compounds such as atrazine postemergent. Storm runoff samples need to becollected several times from several events during the spring and early summer to have a chance at observing the true peak concentrations for the most commonly used herbicides. Second, it is likely that some of the changes in herbicide use and concentration are a result of shifts to other herbicides $(24,27)$. Some of these other herbicides such as the sulfonylureas and imidazolinones are new classes of chemicals that are applied at a fraction of the rate of older compounds. Others, such as acetochlor and dimethenamid, are new to the market but are similar in chemistry and application rate to the older compounds. Analyzing a more complete set of the herbicides that are used in Midwestern agriculture would help to better determine how herbicide concentrations as a whole are changing in Midwestern rivers. Finally, some changes in herbicide concentrations and daily yields presented in this report may be statistically significant only as a result of unknown bias in the timing or method of sample collection. Likewise, some changes in herbicide concentration may be masked by natural variability of herbicide concentrations in streams during runoff events.

\section{Acknowledgments}

This work was supported by the U.S. Environmental Protection Agency, Office of Pesticide Programs, and the USGS's Toxic Substances Hydrology and National Water-Quality Assessment programs. The paper benefited from reviews by C. Crawford, G. Clark, J. Flager, and three anonymous reviewers. The use of trade names in this paper is for identification only and does not imply endorsement by the USGS.

\section{Literature Cited}

(1) Larson, S. J.; Capel, P. D.; Majewski, M. S. Pesticides in Surface Water: Distribution, Trends, and Governing Factors; Ann Arbor Press: Chelsa, MI, 1997.

(2) Richards, R. P.; Baker, D. B. Environ. Toxicol. Chem. 1993, 12 (1), 13.

(3) Ciba-Geigy. A review of historical surface water monitoring for atrazine in the Mississippi, Missouri, and Ohio Rivers; CibaGeigy Corp. Technical Report 6-92, 1992.

(4) Goolsby, D. A.; Pereira, W. E. In Contaminantsin theMississippi River, 1987-92; Meade, R., Ed.; U.S. Geological Survey Circular 1133, 1995; pp 86-101.

(5) Clark, G. M.; Goolsby, D. A.; Battaglin, W. A. Environ. Sci. Technol. 1999, 33 (7), 981.

(6) Kolpin, D. W.; Sneck-Fahrer, D.; Hallberg, G. R.; Libra, R. D. J. Environ. Qual. 1997, 26 (4), 1007.

(7) Saad, D. A. U.S. Geol. Surv. Water-Resour. Inv. Rep. 96-4292, 1997.

(8) Thurman, E. M.; Goolsby, D. A.; Meyer, M. T.; Kolpin, D. W. Environ. Sci. Technol. 1991, 26 (12), 2440.

(9) Thurman, E. M.; Goolsby, D. A.; Meyer, M.T.; Mills, M. S.; Pomes, M. L.; Kolpin, D. W. Environ. Sci. Technol. 1992, 26 (12), 2440.

(10) Goolsby, D. A.; Boyer, L. L.; Battaglin, W. A. Open-FileRep. U.S. Geol. Surv. 1994, 94-347.

(11) Goolsby, D. A.; Battaglin, W. A. In Agrochemical Environmental Fate: State of the Art; Leng, M., Leovey, E., Zubkoff, P., Eds.; CRC Press: Boca Raton, FL, 1995; pp 159-173.

(12) Scribner, E. A.; Goolsby, D. A.; Thurman, E. M.; Battaglin, W. A. Open-File Rep. U.S. Geol. Surv. 1998, 98-181.

(13) Fenelon, J. M. U.S. Geol. Surv. Circ. 1998, 1150.

(14) Donald, W. W.; Hjelmfelt, A. T.; Alberts, E. E. J. Environ. Qual. 1998, 27, 999.

(15) Scribner, E. A.; Goolsby, D. A.; Thurman, E. M.; Meyer, M. T.; Pomes, M. L. Open-File Rep. U.S. Geol. Surv. 1994, 94-396.

(16) Scribner, E. A.; Thurman, E. M.; Goolsby, D. A.; Meyer, M. T.; Mills, M. S.; Pomes, M. L. Open-FileRep. U.S. Geol. Surv. 1993, 93-457.

(17) Thurman, E. M.; Meyer, M. T.;Pomes, M. L.; Perry, C. E.; Schwab, A. P. Anal. Chem. 1990, 62, 2043.

(18) Aga, D. S.; Thurman, E. M.; Pomes, M. L. Anal. Chem. 1994, 66, 1495.

(19) Meyer, M. T. Ph.D. Thesis, University of Kansas, Lawrence, KS, 1994.

(20) TheTriazinePesticides; U.S. Environmental Protection Agency. URL http:// www.epa.gov/ opp00001/ citizens/ triazine.htm, 1997 (accessed Dec 1998).

(21) Ribaudo, M. O.; Bouzaher, A. ERSAgricultural Economic Report 699, U. S. D. A., 1994.

(22) Gianessi, L. P.; Puffer, C. Herbicide Use in the United States; Resources for the Future: Washington, DC, 1991.

(23) Agricultural Resources, Inputs Situation and Outlook Report; U.S. Department of Agriculture, ERS: Washington, DC, 1990; p AR-17. 
(24) Agricultural Chemical Usage, 1990-1996Field Crops Summary; U.S. Department of Agriculture, NASS: Washington, DC, 199197 (published annually).

(25) Iman, R. L.; Conover, W. J. A Modern Approach to Statistics; John Wiley \& Sons: New York, 1993.

(26) Helsel, D. R.; Hirsch, R. M. Statistical Methodsin Water Resources; Elsevier: New York, 1992.
(27) Battaglin, W. A.; Furlong, E. T.; Peter, C. J. U.S. Geol. Surv. Fact Sheet 1998, No. FS-046-98.

Received for review May 6, 1999. Accepted June 2, 1999.

ES9900149 